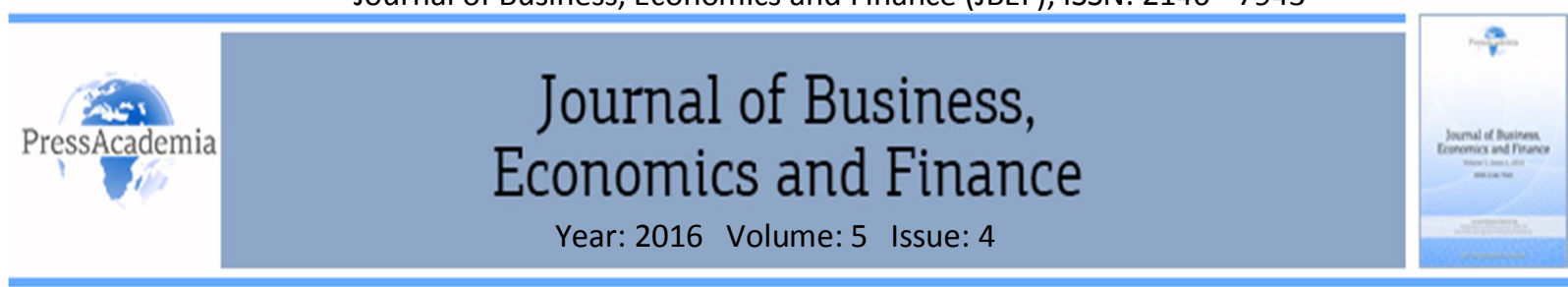

\title{
EFFECT OF FIRM'S EXPORT-ORIENTATION ON BACKWARD SPILLOVERS OF FOREIGN DIRECT INVESTMENT IN TURKISH MANUFACTURING INDUSTRY *
}

DOI: 10.17261/Pressacademia.2017.357

Felor Ebghaei

Hacettepe University. f.ebghaei@hacettepe.edu.tr

\begin{abstract}
This study examines the direct and indirect or spillover effects (horizontal and vertical) of FDI with special emphasis on the backward spillover effects. My main purpose is to examine whether the effect of backward spillovers generated by export oriented foreign owned firms is larger on productivity of domestic firms than backward spillover effect generated by domestic oriented foreign owned firms by using firm-level data for the years 2003-2011. With this purpose, value added and total factor productivity equations with two different measures of backward spillover effects for Turkish manufacturing industry firms are estimated by using the panel data method. My empirical results are consistent with the existence of positive horizontal and vertical spillovers of FDI. My estimation results also show that the backward spillover generated by export oriented foreign owned firms is larger than the backward spillover generated by domestic oriented foreign owned firms.
\end{abstract}

Keywords : Foreign direct investment, spillover effects, backward spillovers, firm exports JEL Classification : F21, F23

\section{INTRODUCTION}

It is argued that there are many potential benefits of FDI and plays a vital role in economic growth. Firstly, FDI increases productivity of domestic firms through the importing of high-tech products and transfer of new technology. De Mello (1997: 9). Moreover, FDI advances technology, management capacity and know-how therefore provides a high level of effectiveness and productivity to the host country. Colen et al. (2008: 13). FDI also can create horizontal and vertical spillovers that increase productivity of domestic firms. Foreign owned firms transfer new technologies and organizational methods to their affiliated firms, also with joint ventures and strategic alliances, importing of capital goods and technology licenses provide positive spillovers to host country directly or indirectly. Blomstrom and Kokko (1998: 3).

FDI spillovers can be formed in the firms that integrated vertically with foreign owned firms (inter-industry) or firms which are in direct competition with them (intra-industry). Intra-industry spillovers or horizontal spillovers occur when foreign owned firms enter into a sector and improve performance and competitiveness of firms in the same sector. The inter-industry or vertical spillovers occur when firms can benefit from the presence of foreign owned firms through forward and backward linkages. This, include firms providing services for FDI firms (Backward Spillover) and also the firms which are provided by FDI firms (Forward Spillover). Stancik (2007: 2).

\footnotetext{
* I wish to thank Prof. Dr. Arzu Akkoyunlu Wigley, Chair of Economics Department of Hacettepe University, for useful comments, discussions and suggestions. I'm grateful to the Turkish State Institute of Statistics (TURKSTAT) for providing access to firm level data under a confidential agreement.
} 


\section{LITERATURE REVIEW}

According to Javorcik (2004), export status of the firm is one of the determinant of the extent of the backward spillover effect generated by foreign owned firms. Javorcik (2004) stated that export oriented foreign owned firms is expected to cause backward spillover more than domestic oriented foreign owned firms since foreign owned firms would have imposed more quality requirements to their domestic suppliers. Although domestic oriented foreign owned firms tend to use domestic resources more than export oriented foreign owned firms, export oriented foreign owned firms use more variety or better quality resources and it can lead to more learning of domestic suppliers and thus it can lead to increased productivity. Therefore, it is expected that exporting firms are associated with the backward spillovers.

Although the productivity effects of horizontal and vertical spillovers have been widely studied, the result of these studies is ambiguous. Some studies found positive evidence of horizontal and vertical spillovers; Reganati and Sica (2005) for Italy, Ayyagari and Kosova (2008) for Czech Republic, Beugelsdijk et al. (2008) for developed countries, Iyer and Stevens (2009) for New Zealand. By contrast, some studies found negative spillover effects; Stancik (2007) for Czech Republic, Mishra (2011) for India. There are also studies pointing out both negative and positive spillover effects; $\mathrm{Xu}$ and Sheng (2012)-positive forward spillover and negative backward spillover for China, Liang (2008)-positive forward spillovers and negative horizontal and backward spillovers. Similarly, Schoors and Van der Tol (2002) and Javorcik (2004) find that the productivity of firms in the manufacturing sector was associated with backward spillovers but no evidence of forward and horizontal spillovers respectively, Hungary and Lithuania.

There are limited number of studies investigating the spillover effects of FDI at firm level in Turkey due to the difficulties in obtaining firm-level data. Taymaz and Yılmaz (2008), found that foreign affiliated firms are more productive than domestic firms for the period 1990-1996. According to Köymen and Sayek (2010), human capital plays a significant role in the transmission of horizontal spillovers, but it does not have any role in the transmission of backward and forward spillovers during the period 1990-2001.

To that end value added and total factor productivity equations for Turkish manufacturing firms for the years 2003-2011 are estimated using the panel data analysis. In the third part of the study, direct and indirect effect of FDI on productivity of domestic firms will be examined. Estimation results are presented in the fourth part of the study. Section five concludes.

\section{DATA AND METHODOLOGY}

In order to determine whether backward spillover effect generated by export oriented foreign owned firms is larger than backward spillover effect generated by domestic oriented foreign owned firms in the Turkish manufacturing industry, Cobb-Douglas production function Equation (1) and Total Factor Productivity (TFP) Equation (2) are estimated.

InValue Added ${ }_{i j t}=\beta_{0}+\beta_{1} \operatorname{lnLabour}_{i j t}+\beta_{2} \ln$ Capital Stock $k_{i j t}+\beta_{3}$ Foreign Capital Share $_{i j t}+\beta_{4}$ Horizontal Spillover $_{j \mathrm{t}}+$ $\beta_{5}$ Backward Spillover (Export-Oriented) $)_{\mathrm{jt}}+\beta_{6}$ Backward Spillover (Domestic-Market-Oriented) $)_{\mathrm{jt}}+\beta_{7}$ Forward Spillover ${ }_{j \mathrm{t}}+$ Year $+\varepsilon_{\mathrm{ijt}}$

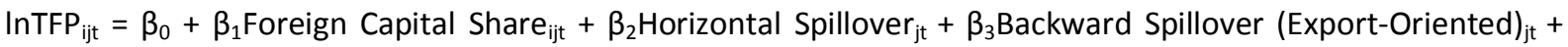
$\beta_{4}$ Backward Spillover (Domestic-Market-Oriented) jt $_{\mathrm{t}}+\beta_{5}$ Forward Spillover $_{\mathrm{jt}}+$ Year $+\varepsilon_{\mathrm{ijt}}$

Where $\mathrm{i}, \mathrm{j}$ and $\mathrm{t}$ denote firm, industry and year respectively. $\operatorname{lnValue} A d d e d_{i j t}$ and $\operatorname{lnTFP} P_{i j t}$ show the natural

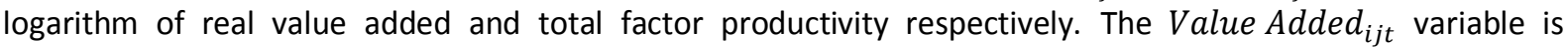
calculated based on the equation

Value Added $_{i j t}=\left(\right.$ Output $_{i j t}-$ Raw materials $_{i j t}-$ Electricity $_{i j t}-$ Fuel $\left._{i j t}\right)$.

Output, Raw materials, Electricity and Fuel variables are deflated by the Domestic Producer Price Index $(2003=100)$ compiled by the Turkish Statistical Institute (TurkStat). InLabour $_{i j t}$ indicates the natural logarithm of labour that I calculated as the sum of paid employees and unpaid family members who work with business owner and partners. InCapital Stock $k_{i j t}$ indicates the natural logarithm of capital stock. Data for the capital 
stock is not available in the database of TurkStat. Therefore, capital stock series of firms are generated based on the building and structure, machinery and equipment, transportation equipment, computer and programming expenses of firms by using the Perpetual Inventory Method following the Berlemann and Wesselhöft (2012). Total Investment Deflator (2003=100), obtained from the Ministry of Development, was

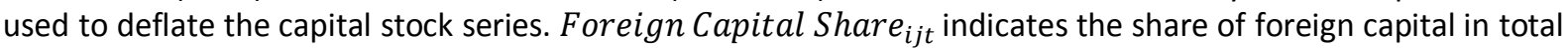
capital of a firm. Horizontal Spillover ${ }_{j t}$, Backward Spillover $_{j t}$ and Forward Spillover $_{j t}$ represent the proxy variables for measuring horizontal and vertical productivity spillovers arising from the foreign presence in upstream and downstream sectors.

Proxy variables for Horizontal, Backward and Forward Spillovers variables are calculated at sectoral level based on 2-digit NACE Rev. 2 classification. As a proxy for the horizontal spillover resulting from the foreign presence

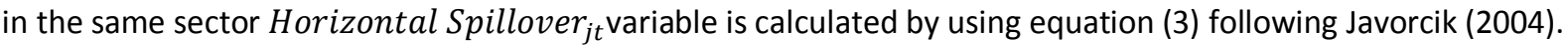
In equation (3), horizontal spillover is defined as foreign equity participation averaged over all firms in the sector, weighted by each firm's share in sectoral output. In the other words, it is defined as the average participation of foreign capital of sector j's all firms.

Horizontal Spillover $_{j t}=\frac{\sum_{i \text { for all i } \epsilon \text { Foreign Capital } \text { Share }_{i t} \times \text { output }_{i t}}}{\sum_{i \text { for all } i \epsilon j} \text { Output }_{i t}}$

Output $_{i t}$ indicates the real output of the firm. The output variable was deflated by Domestic Producer Price Index $(2003=100)$ of TurkStat.

Backward Spillover $_{j t}$ is a proxy for the foreign presence in the industries that are being supplied by sector $\mathrm{j}$. This variable is designed to measure the potential link between domestic suppliers and multinational customers. In order to measure the backward spillover equation (4) is used following Javorcik (2004).

Backward Spillover $(\text { Export - Oriented })_{j t}=$

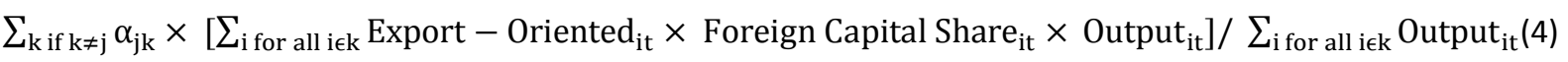
$\alpha_{j k}$ indicates the ratio of inputs purchased by sector $\mathrm{k}$ from sector $\mathrm{j} .{ }^{1}$

Export Oriented $_{i j t}$ is a dummy variable that identifies export oriented firms. If firm $\mathrm{i}$ is exporting at least $20 \%$

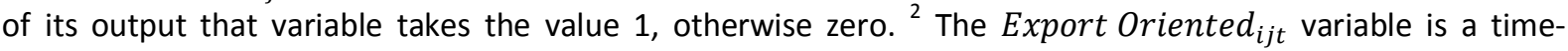
dependent dummy variable.

In addition, backward spillover generated by firms that focused on domestic market (Backward Spillover (Domestic-Market-Oriented)) is calculated similarly.

Backward Spillover $(\text { Domestic }- \text { Market - Oriented })_{j t}=$

$\sum_{\mathrm{k} \text { if } \mathrm{k} \neq \mathrm{j}} \alpha_{\mathrm{jk}} \times\left[\sum_{\mathrm{i} \text { for all iek }}\right.$ Domestic - Market - Oriented $_{\mathrm{it}} \times$ Foreign Capital Share $_{\mathrm{it}} \times$ Output $\left._{\mathrm{it}}\right] /$

$\sum_{\text {i for all i } \epsilon \mathrm{k}}$ Output $_{\text {it }}$

In order to determine the value of domestic orientation of firms I have created the Domestic-Market-Oriented ${ }_{\text {it }}$ variable. If firm $i$ is exporting less than $20 \%$ of its output that variable takes the value 1 , otherwise zero.

Forward Spillover ${ }_{j t}$ represents the weighted share of foreign capital from all sectors that supply sector $\mathrm{j}$. For measuring the forward spillover equation (6) is used following Stancik (2007). This variable measures the spillover resulting from the presence of foreign firms in the upstream sector.

Forward Spillover $_{j t}=\sum_{\mathrm{k} \text { if } \mathrm{k} \neq \mathrm{j}} \alpha_{\mathrm{kj}}$ Horizontal Spillover $_{k t}$

\footnotetext{
${ }^{1}$ The coefficients were calculated by using the year 2002 Input-Output matrix (classified as NACE 2-digit level) produced by TurkStat. The latest Input-Output table available is for the year 2002 (with 2-digit NACE Rev. 1.1 industrial classification). So as a first step, NACE Rev. 1.1 and NACE Rev. 2 Transformation matrix was constructed by using Annual Business Statistics 2009 data and then 2002 Input-Output table was transformed to NACE Rev. 2 CPA 2008 classification.

${ }^{2}$ The frequency distribution of share of export of a firm in its total output shows that the number of firms which exports approximately $20 \%$ of the output is the most commonly observed. Thus, $20 \%$ is chosen as the lower limit for the export orientation variable.
} 
$\alpha_{k j}$ indicates the ratio of inputs purchased by sector $\mathrm{j}$ from sector $\mathrm{k}$.

Griliches and Mairesse (1995) points out the endogeneity of input selection problem in the estimation of production function. According to Griliches and Mairesse (1995), the inputs must be considered endogenous since they are chosen by based on firm productivity, which is observed by the producer but not by the econometrician. OLS method can lead to biased estimates of coefficients if labour and other inputs are assumed to be exogenous variables. Therefore, in order to avoid the simultaneity and selection bias problems created by the OLS method, TFP is estimated by using non-parametric estimation procedure suggested by Levinsohn and Petrin (2003) and semi-parametric estimation method of Olley and Pakes (1996). ${ }^{3}$ Consistent estimates of input coefficients obtained by using Levinsohn and Petrin (2003) and Olley and Pakes (1996) methods for every 2-digit NACE Rev. 2 sector, are used to calculate the total factor productivity. The estimation results of Levinsohn-Petrin and Olley-Pakes coefficients are given in Appendix $1 .{ }^{4}$

The data used in this study was collected from Annual Industry and Service Statistics and Annual Trade Statistics provided by TurkStat. Annual Industry and Service Statistics database constitutes an unbalanced panel for firms with labor force of more than 10 and covering the period of 2003-2011. Annual Industry and Service Statistics contains 417,797 firms and 815,646 observations, Annual Trade Statistics contains 238,736 firms and $15,912,781$ observations. My study includes the manufacturing industry sectors under the classification NACE Rev. 2. ${ }^{5}$

To avoid any possible deviated results, the database was cleared of missing observations and abnormal values. Abnormal observations were discarded based on the cleaning procedure proposed by Hall and Mairesse (1995). I excluded observations displaying extraordinary jumps and drops over one year. The firms with less than 20 employees were also excluded from the sample. Finally, I excluded firms in NACE sectors numbered 12 and 19 since they include a small number of firms. After merging and cleaning procedures, a database of 22 sectors consisting of 39,806 firms and 159,007 observations was constructed. Finally, $\varepsilon_{i j t}$ indicates the error term and Year indicates dummy variable generated for controlling the time-specific effects. Summary statistics of the variables used in the estimations of the study are presented in Appendix 2.

In order to take into account unobservable heterogeneity among firms that is potentially correlated with the dependent variables the fixed effects specification of the panel data was used. Hausman test results also indicate that a fixed effects specification should be employed. According to Aitken and Harrison (1999) and Keller (2004), controlling for unobserved factors (fixed effects) is necessary in order to avoid deviations resulting from endogeneity created by the presence of FDI. According to Hale and Long (2007), the increase in domestic firms' productivity in an industry may correspond to an increase in the presence of FDI in that industry. Therefore, ignoring unobserved factors can lead to a biased regression or simultaneity bias. So, time dummy variables are added in equations to control industry level unobserved heterogeneity. In addition, the standard error should be corrected for clustering because spillover variables are calculated at the sector level but the rest of the variables in the data set are at the firm level. According to Moulton (1990), when aggregate market and public policy variables are used to explain the economic behavior of the micro units, standard errors of the estimated coefficients of total variables can be downward biased so this may lead to the overstated significance of coefficients. Therefore, if the cluster error problem is not solved it may cause a serious downward deviation in the estimated standard error and it can lead to misleading results in the

\footnotetext{
${ }^{3}$ TFP estimation results obtained by Olley and Pakes (1996) method are used for robustness check of the benchmark equations.

${ }_{5}^{4}$ All of the equations are estimated by using the Stata 13.1 software.

${ }^{5}$ Those sectors are; 10. Manufacture of food products, 11. Manufacture of beverages, 12. Manufacture of tobacco products, 13. Manufacture of textiles, 14. Manufacture of wearing apparel, 15. Manufacture of leather and related products, 16. Manufacture of wood and of products of wood and cork, except furniture; manufacture of articles of straw and plaiting materials, 17. Manufacture of paper and paper products, 18. Printing and reproduction of recorded media, 19. Manufacture of coke and refined petroleum products, 20. Manufacture of chemicals and chemical products, 21. Manufacture of basic pharmaceutical products and pharmaceutical preparations, 22. Manufacture of rubber and plastic products, 23. Manufacture of other non-metallic mineral products, 24. Manufacture of basic metals, 25. Manufacture of fabricated metal products, except machinery and equipment, 26. Manufacture of computer, electronic and optical products, 27. Manufacture of electrical equipment, 28. Manufacture of machinery and equipment n.e.c., 29. Manufacture of motor vehicles, trailers and semi-trailers, 30. Manufacture of other transport equipment, 31. Manufacture of furniture, 32. Other manufacturing, 33. Repair and installation of machinery and equipment.
} 
statistical significance of total variables. Moulton (1990: 334). Thus, it is necessary to improve intra-group correlation in the standard errors of observations in the same sector in a particular year. For this purpose, one of the most common approaches in the literature, the general cluster-robust approach, that is used by Aitken and Harrison (1999), Javorcik (2004) and Haskel et al. (2002) is also adopted in this study.

\section{FINDINGS AND DISCUSSIONS}

The estimation results of the equations for value added (Equation (1)) and for total factor productivity (Equation (2)) are presented in Appendix 3.

According to Appendix 3, coefficients of all variables are in accordance with theoretical expectations. The coefficients of Labour and Capital Stock are positive and statistically significant. A $1 \%$ increase in the firm's labour increases the value added of the firm by $0.7755 \%$, a $1 \%$ increase in the capital stock increases the value added of a firm by $0.0590 \% .{ }^{6}$ The direct effects of FDI, which is represented by the Foreign Capital Share variable, have a positive and significant effect. A one unit increase in the Foreign Capital Share increases the productivity of domestic firms by $0.09 \%$ in Equation (1) and $0.02 \%$ in Equation (2). This result shows that the direct effect of foreign direct investment contributes to increase productivity of firms. This positive effect might arise because FDI increases the accumulation of capital in the manufacturing industry of Turkey, allowing the use of new intermediate goods and technology in accordance with theoretical expectations. In other words, positive coefficient shows that FDI increases production of firms directly through increasing of capital in Turkish manufacturing industry. In the case of indirect effects of foreign direct investment (spillover effects), Horizontal Spillover variable is positive and statistically significant in both of the equations. According to this result, one unit increase in foreign presence in a specific sector increases the productivity of firms by $0.11 \%$ in Equation (1) and $0.22 \%$ in Equation (2). The positive coefficients of horizontal spillover show that competitive effects, knowhow and technology spillovers generated by the presence of FDI happen in the Turkish manufacturing industry. When vertical spillover components are issue, the coefficients of Forward Spillover are positive and significant in both of the equations. One unit increase in foreign presence in a sector increases the productivity of firms by $0.24 \%$ in Equation (1) and $0.80 \%$ in Equation (2). This result shows that the performance of domestic firms which is provided by the foreign owned firms affected positively by presence of foreign owned firms in the Turkish manufacturing industry. The coefficients of Backward Spillover (Export-Oriented) are positive and significant in both of the equations. One unit increase in Backward Spillover (Export-Oriented) increases the productivity of firms by $0.38 \%$ in Equation (1) and $0.30 \%$ in Equation (2). Coefficient of Backward Spillover (Domestic-Market-Oriented) is statistically significant in Equation (2). According to this, one unit increase in Backward Spillover (Domestic-Market-Oriented) increases the productivity of firms by $0.06 \%$. The results of vertical spillovers show that domestic firms which are not in the foreign owned firms sectors but they have a direct business relationship with foreign owned firms can benefit from presence of foreign owned firms. These results include firms providing goods and services for foreign owned firms (Backward Spillover) and also the firms which are provided by foreign owned firms (Forward Spillover). According to Javorcik (2004), both of Backward Spillover (Export-Oriented) and Backward Spillover (Domestic-Market-Oriented) are significant but in Turkey contrariwise to Lithuania, coefficient of Backward Spillover (Export-Oriented) is larger.

To ensure the robustness of my findings to the measurement of alternative methods for calculating TFP, that variable is also estimated using the Olley and Pakes (1996) method. The last column of Appendix 3 shows the estimation results when the TFP obtained by using the method of Olley and Pakes (1996) is used as the dependent variable. As with the results obtained using the Levinsohn and Petrin (2003) method, the sign of the coefficients of all variables are as theoretically expected and the coefficient of Backward Spillover (ExportOriented) is larger than Backward Spillover (Domestic-Market-Oriented).

I also checked whether my results are sensitive to alternative methods of measuring the spillover variables. With this aim, the Horizontal Spillover variable that measures foreign presence in the same sector (equation 3) is recalculated as foreign capital share is used as a dummy variable (if the firm $\mathrm{i}$ is foreign-owned, its value is 1 ,

\footnotetext{
${ }^{6}$ As with the results obtained by Konings (2001), Driffield et al. (2002), Reganati and Sica (2005), Stancik (2007), Blalock and Gertler (2008), Kolasa (2008) and Mishra (2011), the coefficient of labour is greater than the coefficient of capital in my study.
} 
otherwise, its value is zero), following Kolasa (2008). Accordingly, the Backward Spillover and Forward Spillover variables were recalculated using the above mentioned dummy variable and then all of equations were reestimated using those new spillover variables. The estimation results for both value added as well as total factor productivity equations are not significantly different from the results presented in Appendix 3 .

\section{CONCLUSION}

This study examines the effect of horizontal spillover and vertical spillover generated by FDI on productivity of firms in the Turkish manufacturing industry by using the firm-level data. The effect of backward spillover was investigated into two groups; the effect of backward spillover generated by export oriented foreign owned firms and the effect of backward spillover generated by domestic oriented foreign owned firms. With that aim, value added and total factor productivity equations were estimated for the Turkish manufacturing industry firms by using panel data analysis for the period 2003-2011. My estimation results indicate that direct productivity increasing effect of FDI and the horizontal and vertical spillover effects of FDI increases the productivity of firms in the Turkish manufacturing industry. Estimation results of the effect of backward spillover generated by export oriented foreign owned firms and domestic oriented foreign owned firms are positive and significant for both of value added and total factor productivity equations. In addition, backward spillover generated by export oriented foreign owned firms is larger than the backward spillover generated by domestic oriented firms. My results are robust to the use of alternative measures of TFP and productivity spillovers variables.

\section{REFERENCES}

Aitken, B.J. \& Harrison, A.E. 1999, "Do Domestic Firms Benefit From Foreign Direct Investment? Evidence from Panel Data", American Economic Review, vol. 89, no. 3, pp. 605-618.

Ayyagari, M. \& Kosova, R. 2008, "Does FDI facilitate Domestic Entry? Evidence from the Czech Republic", Can be downloaded at: http://ssrn.com/abstract=891781 (retrieved 20.09. 2014).

Berlemann, M. \& Wesselhöft, J. E. 2012, "Estimating Aggregate Capital Stocks Using the Perpetual Inventory Method", Working Paper, no. 125.

Beugelsdijk, S., Smeets, R. \& Zwinkels, R. 2008, "The Impact of Horizontal and Vertical FDI on Host's Country Economic Growth", International Business Review, no. 17, pp. 452-472.

Blalock, G. \& Gertler, P. 2008, "Welfare Gains from Foreign Direct Investment through Technology Transfer to Local Suppliers", Journal of International Economics, no. 74, pp. 402-421.

Blomstrom, M. \& Kokko, A. 1998, "Multinational Corporations and Spillovers", Journal of Economic Surveys, vol. 12, no. 2, pp. 1-31.

Colen, L., Maertens, M. \& Swinnen, J. 2008, "Foreign Direct Investment as an Engine for Economic Growth and Human Development: A Review of the Arguments and Empirical Evidence", Working Paper, no. 16, pp. 1-48.

De Mello, J. 1997, "Foreign Direct Investment in Developing Countries and Growth: A Selective Survey", Journal of Development Studies, vol. 1, no. 34, pp. 1-34.

Driffield, N., Munday, M. \& Roberts, A. 2002, "Foreign Direct Investment, Transactions Linkages, and the Performance of the Domestic Sector", International Journal of the Economics of Business, vol. 9, no. 3, pp. 335-351.

Griliches, Z. \& Mairesse, J. 1995, "Production Functions: the Search for Identification", NBER Working Paper, no. 5067.

Hale, G. \& Long, C. 2007, "Are there Productivity Spillovers from Foreign Direct Investment in China? ", Working Paper Series, Federal Reserve Bank of San Francisco.

Hall, B.H. \& Mairesse, J. 1995, "Exploring the Relationship between R\&D and Productivity in French Manufacturing Firms", Journal of Econometrics, no. 65, pp. 263-293.

Haskel, J.E., Pereira, S.C. \& Slaughter, M.J. 2002, "Does Inward Foreign Direct Investment Boost the Productivity of Domestic Firms? ", NBER Working Paper, no. 8724.

Iyer, K. \& Stevens, P. 2009, "Productivity Spillovers from Foreign Direct Investment in New Zealand Manufacturing", The New Zealand Association of Economists (NZAE) Conference: 1-3 July- Wellington. 
Javorcik, S.B. 2004, "Does Foreign Direct Investment Increase the Productivity of Domestic Firms? In Search of Spillovers through Backward Linkages", The American Economic Review, vol. 94, no. 3, pp. 605-627.

Keller, W. 2004, "International Technology Diffusion", Journal of Economic Literature, no. XLII, pp. 752-782.

Kolasa, M. 2008, "How does FDI Inflow Affect Productivity of Domestic Firms? The Role of Horizontal and Vertical Spillovers, Absorptive Capacity and Competition", The Journal of International Trade and Economic Development: An International and Comparative Review, vol. 17, no. 1, pp. 155-173.

Konings, J. 2001, "The Effects of Direct Foreign Investment on Domestic Firms: Evidence from Firm Level Panel Data in Emerging Economies", Economics of Transition, vol. 9, no. 3, pp. 619-633.

Köymen, S. \& Sayek, S. 2010, "The Role of Human Capital In Productivity Spillovers from FDI: An Empirical Analysis on Turkish Manufacturing Firms", Discussion Papers, Bilkent University, no. 10-03.

Liang, F.H. 2008, "Does Foreign Direct Investment Improve the Productivity of Domestic Firms? Technology Spillovers, Industry Linkages, and Firm Capabilities", Can be downloaded at: http://ssrn.com/abstract=1479837 (retrieved 12.04. 2014).

Mishra, B.R. 2011, "Spill-over Effects of Foreign Direct Investment: An Econometric Study of Indian Firms", Munich Personal RePEc Archive (MPRA), no. 37759.

Moulton, B.R. 1990, "An Illustration of a Pitfall in Estimating the Effects of Aggregate Variables on Micro Units", The Review of Economics and Statistics, vol. 72, no. 2, pp. 334-338.

Reganati, F. \& Sica, E. 2005, "Do Domestic Firms Benefit from the Presence of MNEs? The Case of the Italian Manufacturing Sector", Dipartimento di Scienze Economiche, Matematiche e Statistiche, no. 23, pp. 1-15.

Schoors, K. \& Van der Tol, B. 2002, "Foreign Direct Investment Spillovers within and between Sectors: Evidence from Hungarian Data", Working Paper, no. 157, pp. 1-29.

Stancik, J. 2007, "Horizontal and Vertical FDI Spillovers: Recent Evidence from the Czech Republic", Working Paper Series, no. 340, pp. 1-36.

Taymaz, E. \& Yılmaz, K. 2008, "Foreign Direct Investment and Productivity Spillovers", Working Papers and Koc University.

Turkish Statistical Institute, Annual Industry and Service Statistics, TURKSTAT, Ankara.

Turkish Statistical Institute, Annual Trade Statistics, TURKSTAT, Ankara.

Xu, X. \& Sheng, Y. 2012, "Productivity Spillovers from Foreign Direct Investment: Firm-Level Evidence from China", World Development, vol. 40, no. 1, pp. 62-74. 
Appendix 1: Estimation Results of the Production Function

\begin{tabular}{|c|c|c|c|c|}
\hline & \multicolumn{2}{|c|}{ Levinsohn-Petrin Method } & \multicolumn{2}{c|}{ Olley-Pakes Method } \\
\hline NACE & InLabour & InCapital Stock & InLabour & InCapital Stock \\
\hline 10 & 0.6643396 & 0.3690162 & 0.9001304 & 0.3854903 \\
\hline 11 & 0.6562387 & 0.1099754 & 1.10636 & 0.1710952 \\
\hline 13 & 0.6065918 & 0.2619154 & 0.8402271 & 0.2768331 \\
\hline 14 & 0.602835 & 0.0995597 & 0.8503689 & 0.3518474 \\
\hline 15 & 0.6373821 & 0.288632 & 0.8547244 & 0.4227617 \\
\hline 16 & 0.7780355 & 0.3809461 & 1.15912 & 0.2335914 \\
\hline 17 & 0.6661604 & 0.1572146 & 1.142118 & 0.1617897 \\
\hline 18 & 0.7894822 & 0.3499856 & 1.096053 & 0.4295174 \\
\hline 20 & 0.6225729 & 0.1543822 & 0.8818092 & 0.2962203 \\
\hline 21 & 0.7576247 & 0.3980981 & 0.8711153 & 0.0138103 \\
\hline 22 & 0.6966312 & 0.1336371 & 0.9625531 & 0.3032417 \\
\hline 23 & 0.7031888 & 0.4635353 & 0.8754299 & 0.505786 \\
\hline 24 & 0.7932771 & 0.1068973 & 0.9885009 & 0.2419338 \\
\hline 25 & 0.6613395 & 0.2718319 & 0.8659006 & 0.2689197 \\
\hline 26 & 0.5632432 & 0.7115465 & 0.871297 & 0.6925946 \\
\hline 27 & 0.7866029 & 0.0900711 & 1.008095 & 0.1294716 \\
\hline 28 & 0.6496103 & 0.3584798 & 1.006742 & 0.1874356 \\
\hline 29 & 0.7662098 & 0.3986395 & 1.005509 & 0.4400386 \\
\hline 30 & 0.604252 & 0.1904869 & 0.8345395 & 0.4138524 \\
\hline 31 & 0.6847619 & 0.3759167 & 0.9875932 & 0.187478 \\
\hline 32 & 0.7517591 & 0.4653771 & 0.8706252 & 0.4506237 \\
\hline 33 & 0.6713068 & 0.750807 & 0.82576 & 0.5897504 \\
\hline & & & & \\
\hline
\end{tabular}

Appendix 2: Summary Statistics for the Variables

\begin{tabular}{|c|c|c|c|c|c|c|}
\hline & \multicolumn{3}{|c|}{$\begin{array}{c}\text { Statistical Summary for the Variables } \\
\text { Used in Main Models }\end{array}$} & \multicolumn{2}{c|}{$\begin{array}{c}\text { Summary for the Variables Used for } \\
\text { the Robustness Check }\end{array}$} \\
\hline & Obs. No & Mean & Std. Error & Obs. No & Mean & Std. Error \\
\hline InValue Added & 151,601 & 13.88 & 1.41 & & & \\
\hline InTFP_LP & 137,470 & 1.93 & 0.43 & & & 0.42 \\
\hline InTFP_OP & & & & 137,588 & 1.66 & \\
\hline InLabour & 155,347 & 4.01 & 0.86 & & & \\
\hline InCapital Stock & 143,384 & 14.60 & 1.90 & & & \\
\hline Foreign Capital Share & 159,007 & 2.67 & 14.82 & & & \\
\hline Horizontal Spillover & 159,007 & 11.41 & 10.98 & 159,007 & 0.18 & 0.16 \\
\hline $\begin{array}{c}\text { Backward Spillover } \\
\text { (Export-Oriented) }\end{array}$ & 159,007 & 172.26 & 247.67 & 159,007 & 2.34 & 3.25 \\
\hline $\begin{array}{c}\text { Backward Spillover } \\
\text { (Domestic-Market- }\end{array}$ & 159,007 & 390.91 & 641.83 & 159,007 & 6.68 & 12.52 \\
\hline $\begin{array}{c}\text { Oriented) } \\
\text { Forward Spillover }\end{array}$ & 159,007 & 564.34 & 1370.25 & 159,007 & 9.04 & 21.45 \\
\hline
\end{tabular}


Appendix 3: Export, Spillovers and Productivity; Fixed Effects Model

\begin{tabular}{|c|c|c|c|}
\hline & $\begin{array}{l}\text { Equation } \\
\text { (1) }\end{array}$ & $\begin{array}{l}\text { Equation } \\
\text { (2) }\end{array}$ & $\begin{array}{l}\text { Equation } \\
(2) \\
\text { Olley-Pakes } \\
\text { Method }\end{array}$ \\
\hline Labour & $\begin{array}{c}0.7755^{* * *} \\
(0.0099)\end{array}$ & & \\
\hline Capital Stock & $\begin{array}{c}0.0590 * * * \\
(0.0058)\end{array}$ & & \\
\hline Foreign Capital Share & $\begin{array}{c}0.0009 * * \\
(0.0004)\end{array}$ & $\begin{array}{l}0.0002^{*} \\
(0.0001)\end{array}$ & $\begin{array}{c}0.0002 * * * \\
(0.0001)\end{array}$ \\
\hline Horizontal Spillover & $\begin{array}{l}0.0011^{*} \\
(0.0006)\end{array}$ & $\begin{array}{c}0.0022 * * * \\
(0.0006)\end{array}$ & $\begin{array}{c}0.0013^{* *} \\
(0.0006)\end{array}$ \\
\hline $\begin{array}{c}\text { Backward Spillover (Export- } \\
\text { Oriented) }\end{array}$ & $\begin{array}{c}0.0038 * * * \\
(0.0011)\end{array}$ & $\begin{array}{l}0.0030 * * * \\
(0.0004)\end{array}$ & $\begin{array}{c}0.0027 * * * \\
(0.0004)\end{array}$ \\
\hline $\begin{array}{c}\text { Backward Spillover (Domestic- } \\
\text { Market-Oriented) }\end{array}$ & $\begin{array}{c}0.0015 \\
(0.0048)\end{array}$ & $\begin{array}{c}0.0006 * * * \\
(0.0002)\end{array}$ & $\begin{array}{c}0.0009 * * * \\
(0.0002)\end{array}$ \\
\hline Forward Spillover & $\begin{array}{l}0.0024^{*} \\
(0.0013)\end{array}$ & $\begin{array}{c}0.0080 * * \\
(0.0036)\end{array}$ & $\begin{array}{c}0.0028 * * * \\
(0.0004)\end{array}$ \\
\hline Year Dummy & Evet & Evet & Evet \\
\hline Constant & $\begin{array}{c}9.8226 * * * \\
(0.0870)\end{array}$ & $\begin{array}{c}1.8924 * * * \\
(0.0075)\end{array}$ & $\begin{array}{c}1.6719 * * * \\
(0.0071)\end{array}$ \\
\hline Number of Observations & 138,192 & 137,470 & 137,588 \\
\hline Number of Groups & 32,409 & 32,254 & 32,355 \\
\hline $\mathrm{R}^{2}$ : Within & 0.1937 & 0.0450 & 0.0260 \\
\hline $\mathrm{R}^{2}$ : Between & 0.6075 & 0.0110 & 0.0330 \\
\hline $\mathrm{R}^{2}:$ Overall & 0.6162 & 0.0230 & 0.0440 \\
\hline F-Statistic & 759.91 & 20.88 & 22.31 \\
\hline Prob $>\mathrm{F}$ & 0.0000 & 0.0000 & 0.0000 \\
\hline Chi $^{2}$-Statistic & 2202.98 & 2063.15 & 2197.01 \\
\hline Prob $>\mathrm{Chi}^{2}$ & 0.0000 & 0.0000 & 0.0000 \\
\hline
\end{tabular}

Note: Robust standard errors are in parentheses; these errors have been corrected for clustering in each year and sector; '*' '**', '***' indicate significant value at $10 \%, 5 \%$ and $1 \%$ level of significance respectively. 